\title{
UPAYA MENINGKAKAN KEAKTIFAN BELAJAR SISWA KOMPETENSI DASAR PADA PEMBELAJARAN IPA DENGAN MENGGUNAKAN METODE EKSPERIMEN KELAS IX 8 SMP NEGERI 4 TEBING TINGGI
}

\author{
Abd. Kadir \\ Surel: abdkadir1102@gmail.com
}

\begin{abstract}
ABSTRAK
Penelitian di SMP Negeri 4 Tebing Tinggi ini dilakukan dengan tujuan untuk mengetahui penggunaan metode eksperimen dalam meningkatkan keaktifan belajar siswa. Subjek dalam penelitian ini siswa kelas IX.8 SMP Negeri 4 Tebing Tinggi sebanyak satu kelas yang berjumlah 35 siswa. Hasil temuan penelitian persentasi hasil keaktifan belajar siswa berdasarkan pengamatan observer pada tindakan siklus I pertemuan I yaitu 71,52\% (cukup aktif), siklus I pertemua II yaitu $72,30 \%$ (cukup aktif), sedangkan persentasi hasil keaktifan belajar siswa pada tindakan siklus II pertemuan I yaitu 82,30\% (aktif), siklus II pertemuan II yaitu $84,01 \%$ (aktif). Hasil pengamatan guru kelas tentang penerapan metode eksperimen tindakan siklus I pertemuan I yaitu $68,75 \%$ (kurang baik), dan tindakan siklus I pertemuan II yaitu 78,12\% (cukup baik), sedangkan hasil pengamatan guru kelas tentang penerapan metode eksperimen tindakan siklus II pertemuan I yaitu 87,5\% (baik) dan tindakan siklus II pertemuan II yaitu 93,75\% (sangat baik).
\end{abstract}

Kata kunci: Eksperimen, Meningkatkan, Menggunakan.

\section{PENDAHULUAN}

Pendidikan sangat penting dalam meningkatkan potensi diri setiap orang. Pendidikan merupakan usaha sadar dan terencana untuk mewujudkan suasana belajar dalam proses pembelajaran agar siswa secara aktif mengembangkan potensi dirinya. Salah satu lembaga pendidikan adalah sekolah. Sekolah merupakan lembaga pendidikan yang mempunyai tugas untuk mengembangkan segala potensi yang dimiliki oleh siswa, demikian juga dengan Sekolah menengah pertama. Pengembangan potensi yang dimiliki masing-masing siswa dengan optimal, akan meningkatkan taraf kehidupannya kelak. Untuk itu perlu diperhatikan atau diupayakan semua komponen-komponen dalam proses belajar mengajar agar saling mendukung sehingga tercapai hasil belajar yang baik.

Belajar mengajar selaku suatu sistem instruksional mengacu kepada pengertian sebagai seperangkat komponen yang saling bergantung satu sama lain untuk mencapai tujuan. Selaku suatu sistem, belajar mengajar meliputi suatu komponen, antara lain tujuan, bahan, siswa, guru, metode, situasi, dan evaluasi. Agar tujuan itu tercapai, semua komponen yang ada harus diorganisasikan sehingga antar sesama komponen terjadi kerjasama. Karena itu, guru tidak boleh hanya memperhatikan komponen-komponen tertentu saja misalnya metode, bahan, dan evalusi saja, tetapi ia harus mempertimbangkan komponen belajar mengajar secara keseluruhan (Djamarah, 2006:9).

Faktor keaktifan siswa sebagai 
subjek belajar sangat menentukan keberhasilan siswa dalam menguasai bahan pelajaran. Memang pada kegiatan di masa-masa lalu banyak interaksi belajar mengajar yang berjalan secara searah. Dalam hal ini fungsi dan peran guru menjadi sangat dominan, di lain pihak siswa hanya menyimak dan mendengarkan informasi atau pengetahuan yang diberikan gurunya. Ini menjadikan kondisi yang tidak proporsional dan guru sangat aktif, tetapi sebaliknya siswa menjadi pasif dan tidak kreatif. Bahkan kadang-kadang masih ada anggapan yang keliru yang memandang siswa sebagai objek. Sehingga siswa kurang dapat mengembangkan potensinya. Pandangan dan kegiatan interaksi belajar mengajar semacam ini tidak benar. Sebab dalam konsep belajar mengajar, siswa/ anak didik adalah subjek belajar, bukan objek, sebagai unsur manusia yang pokok dan sentral, bukan unsur pendukung atau tambahan. Yang penting dalam interaksi belajar mengajar adalah guru sebagai pengajar tidak mendominasi kegiatan, tetapi membantu menciptakan kondisi yang kondusif serta memberikan motivasi dan bimbingan agar siswa dapat mengembangkan potensi dan kreativitasnya, melalui kegiatan belajar. Diharapkan potensi siswa dapat sedikit demi sedikit berkembang menjadi komponen penalaran yang bermoral, manusiamanusia aktif dan kreatif yang beriman. Dalam kegiatan belajar mengajar terjadi interaksi antara siswa dan guru. Siswa perlu dididik untuk menjalankan program dan mencapai tujuan belajar. Salah satu tugas pendidik/guru adalah menciptakan suasana pembelajaran yang dapat membuat keadaan siswa menjadi senantiasa belajar dengan baik dan bersemangat. Suasana pembelajaran yang demikian akan berdampak positif dalam pencapaian prestasi belajar yang optimal, karena siswa melakukan dan mengalami sendiri aktivitas pembelajaran tersebut. Dari segi proses, guru dikatakan berhasil apabila mampu melibatkan sebagian besar siswa aktif baik fisik, mental maupun sosial dalam proses pembelajaran. Sedangkan dari segi hasil, guru dikatakan berhasil apabila pembelajaran yang diberikannya mampu mengisi dan merubah perilaku siswa kearah penguasaan kompetensi yang lebih baik, dengan kata lain guru berpengaruh besar terhadap keberhasilan belajar siswa. Berdasarkan hasil observasi selama ini diperoleh $55 \%$ siswa yang tuntas belajar dan $45 \%$ siswa yang tidak tuntas dalam belajar yang dilaksanakan pada pretes. Hal ini disebabkan karena kurangnya keaktifan siswa selama proses belajar mengajar yang berlangsung di dalam kelas. Keaktifan siswa selama kegiatan pembelajaran berlangsung tergolong kurang, karena siswa jarang mengajukan pendapat maupun menanyakan materi yang kurang dipahaminya dari apa yang dijelaskan guru. Jika dilihat dari mata pelajaran yang dipelajari yaitu sains/IPA 
seharusnya menuntut siswa untuk terlibat secara aktif, sehingga pembelajaran IPA tersebut lebih bermakna dan jauh lebih lama melekat di ingatan siswa.

Guru hanyalah merangsang keaktifan belajar siswa dengan jalan menyajikan bahan pelajaran dengan menggunakan metode pembelajaran yang tepat, sedangkan yang mengolah dan mencerna adalah siswa itu sendiri. Metode yang diharapkan tepat dalam pembelajaran IPA adalah metode eksperimen. Dengan menerapkan metode eksperimen ketika proses belajar mengajar berlangsung di dalam kelas siswa belajar dan berbuat secara langsung tentang apa yang akan dipelajarinya melalui materi yang disampaikan oleh guru. Melalui pelaksanaan metode eksperimen siswa melakukan berbagai aktivitas yang menyenangkan yang tentunya mampu merangsang munculnya keaktifan belajar. Dengan kata lain melalui penggunaan metode eksperimen siswa berpartisipasi aktif dan memperoleh pengalaman langsung, serta dapat mengembangkan kecakapannya. Uraian di atas menjelaskan bahwa penerapan metode eksperimen dapat menentukan peningkatan keaktifan belajar siswa, prediksi ini dapat dilakukan dengan melaksanakan penelitian yang berjudul: "Upaya Meningkatkan Keaktifan Belajar Siswa Kompetensi Dasar Sistem Reproduksi pada manusia Pembelajaran IPA Dengan Menggunakan Metode Eksperimen
Kelas IX.8 SMP Negeri 4 Tebing Tinggi Tahun Pelajaran 2017/2018".

Sesuai dengan latar belakang masalah maka dapat diidentifikasi masalah yang berkaitan dengan keaktifan belajar siswa:

a. Proses belajar mengajar dalam kelas didominasi oleh guru

b. Metode yang digunakan guru dalam pembelajaran hanya metode ceramah dan pemberian tugas

c. Siswa jarang mengajukan pendapat maupun pertanyaan terhadap penjelasan guru

d. Siswa lebih banyak menunggu sajian dari guru daripada mencari dan menemukan sendiri pengetahuan, keterampilan serta sikap yang mereka butuhkan

e. Kurangnya minat dan motivasi siswa dalam pembelajaran

Berdasarkan latar belakang dan identifikasi masalah di atas dapat diketahui bahwa keaktifan belajar itu dapat dipengaruhi oleh beberapa faktor, namun dalam penelitian ini hanya dibatasi pada penggunaan metode eksperimen dalam meningkatkan keaktifan belajar siswa pada pelajaran IPA di kelas IX.8 SMP Negeri 4 Tebing Tinggi.

Berdasarkan pembatasan masalah di atas maka rumusan masalah pada penelitian ini adalah: apakah dengan menggunakan metode eksperimen dapat meningkatkan keaktifan belajar siswa pada pelajaran IPA di kelas IX.8 SMP Negeri 4 Tebing Tinggi.

Tujuan penelitian ini adalah : untuk meningkatkan keaktifan belajar 
Abd. Kadir : Upaya Meningkatkan Keaktifan ...

siswa pada pelajaran IPA dengan menggunakan metode eksperimen di kelas IX.8 SMP Negeri 4 Tebing Tinggi.

Secara umum IPA dipahami sebagai ilmu yang lahir dan berkembang lewat langkah-langkah observasi, perumusan masalah, penyusunan hipotesis, pengujian hipotesis melalui eksperimen, penarikan kesimpulan, serta penemuan teori dan konsep. Dapat pula dikatakan bahwa IPA adalah ilmu pengetahuan yang mempelajari gejala-gejala melalui serangkaian proses yang dikenal dengan proses ilmiah yang dibangun atas dasar sikap ilmiah dan hasilnya terwujud sebagai produk ilmiah yang tersusun atas tiga komponen terpenting berupa konsep, prinsip, dan teori yang berlaku secara universal. Djamarah (2006:84) mengemukakan tentang metode eksperimen bahwa "metode eksperimen adalah cara penyajian pelajaran dimana siswa melakukan percobaan dengan mengalami dan membuktikan sendiri sesuatu yang dipelajari”. Dalam proses belajar mengajar dengan melakukan percobaan ini siswa diberi kesempatan untuk mengalami sendiri atau melakukan sendiri, mengikuti suatu proses mengamati suatu objek, menganalisis, membuktikan dan menarik kesimpulan sendiri mengenai suatu objek keadaan atau proses sesuatu. Dengan demikian, siswa dituntut untuk mengalami sendiri mencari kebenaran atau mencoba mencari sesuatu, hukum atau dalil/dan menarik kesimpulan atas proses yang dialaminya itu. Roestiyah

(2008:80) mengemukakan bahwa metode eksperimen adalah salah satu cara mengajar, dimana siswa melakukan suatu percobaan tentang sesuatu hal; mengamati prosesnya serta menuliskan hasil percobaannya, kemudian hasil pengamatan itu disampaikan ke kelas dan dievaluasi oleh guru.

Risk (dalam Rohani 2010:7-8) dalam bukunya Principles and practices of Teaching (1958) halaman 7 mengemukakan tentang belajar mengajar sebagai berikut: Teaching is the guidance of learning experiences (mengajar adalah proses membimbing pengalaman belajar). Pengalaman itu sendiri hanya mungkin diperoleh jika peserta didik itu dengan keaktifannya sendiri bereaksi terhadap lingkungannya. Guru dapat membantu peserta didik belajar tetapi guru tidak dapat belajar dari anak itu. Jika seorang peserta didik ingin memecahkan suatu problem, ia harus berpikir menurut langkah-langkah tertentu. Kalau ia ingin menguasai suatu keterampilan, ia harus berlatih mengkordinasikan otot-otot tertentu. Kalau ia ingin memiliki sikap-sikap tertentu ia harus memiliki sejumlah pengalaman emosional, begitu seterusnya.

Dengan demikian, belajar yang berhasil mesti melalui berbagai macam aktivitas, baik aktivitas fisik maupun psikis. Aktivitas fisik ialah peserta didik dengan aktif-giat dengan anggota badan, membuat sesuatu, bermain ataupun bekerja, ia tidak 
hanya duduk dan mendengarkan, melihat atau hanya pasif. Peserta didik yang memiliki aktivitas psikis (kejiwaan) adalah jika daya jiwanya bekerja sebanyak-banyaknya atau banyak berfungsi dalam rangka pengajaran. Seluruh peranan dan kemauan dikerahkan dan diarahkan supaya daya itu tetap aktif untuk mendapatkan hasil pengajaran yang optimal sekaligus mengikuti proses pengajaran (proses perolehan hasil pengajaran) secara aktif, ia mendengarkan, mengamati, menyelidiki, mengingat, menguraikan, mengasosiasikan ketentuan satu dengan lainnya, dan sebagainya. Kegiatan/keaktifan jasmani fisik sebagai kegiatan yang tampak bila ia sedang mengamati dengan teliti, memecahkan persoalan, dan mengambil keputusan, dan sebagainya.

\section{METODE PENELITIAN}

Metode pembelajaran eksperimen dilandasi oleh teori belajar kognitivisme. Peneliti yang mengembangkan teori kognitif ini adalah Ausubel, Bruner, dan Gagne . Teori kognitif ini memiliki perspektif bahwa para peserta didik memproses infromasi dan pelajaran melalui upayanya mengorganisir, menyimpan, dan kemudian menemukan hubungan antara pengetahuan yang baru dengan pengetahuan yang telah ada. Metode pembelajaran eksperimen adalah metode mengajar yang mengatur pengajaran sedemikian rupa sehingga anak memperoleh pengetahuan yang sebelumnya belum diketahuinya itu tidak melalui pemberitahuan, sebagian atau seluruhnya ditemukan sendiri. Dalam pembelajaran eksperimen kegiatan atau pembelajaran yang dirancang sedemikian rupa sehingga siswa dapat menemukan konsep-konsep dan prinsip-prinsip melalui proses mentalnya sendiri. Dalam menemukan konsep, siswa melakukan pengamatan, menggolongkan, membuat dugaan, menjelaskan, menarik kesimpulan dan sebagainya untuk menemukan beberapa konsep atau prinsip.

Ilmu Pengetahuan Alam (IPA) merupakan ilmu yang pokok bahasannya adalah alam dengan segala isinya. Hal yang dipelajari dalam IPA adalah sebab akibat, hubungan kausal dari kejadiankejadian yang ada di alam. Pendidikan IPA diarahkan untuk mencari tahu dan berbuat sehingga dapat membantu siswa untuk memperoleh pemahaman yang lebih mendalam tentang alam sekitar, yang berarti dalam mempelajari IPA perlu adanya keaktifan siswa untuk mempelajari IPA tersebut. Melalui pembelajaran IPA di sekolah siswa dilatih berpikir, membuat konsep ataupun dalil melalui pengamatan. Dalam membahas IPA tidak cukup hanya menekankan pada produk tapi yang lebih penting adalah membuktikan atau mendapatkan suatu teori. Oleh karena itu, seorang guru harus mampu merancang skenario pembelajaran yang mampu memunculkan keaktifan belajar dan peran serta siswa sebagai subjek dari 
Abd. Kadir : Upaya Meningkatkan Keaktifan ...

kegiatan pengajaran, termasuk pemilihan dan penggunaan metode pembelajaran yang tepat dalam proses belajar mengajar. Salah satu metode yang dapat diterapkan untuk meningkatkan keaktifan belajar siswa di SMP Negeri 4 Tebing Tinggi pada pelajaran IPA pokok bahasan Sistem Reproduksi pada manusia adalah dengan menggunakan metode eksperimen.

Berdasarkan kerangka teori dan kerangka konseptual maka dapat diajukan hipotesis sementara sebagai berikut: Melalui penggunaan metode eksperimen pada pelajaran IPA, keaktifan belajar siswa dapat berjalan dengan baik di kelas IX.8 SMP Negeri 4 Tebing Tinggi.

Penelitian ini dilakukan di SMP Negeri 4. J1 DI.Panjaitan No.37 Kota Tebing Tinggi.

\section{Subjek dan Objek Penelitian}

a. Subjek dalam penelitian ini adalah siswa kelas IX.8 SMP Negeri 4 Tebing Tinggi yang berjumlah 35 orang siswa lakilaki 16 orang dan perempuan 19 orang.

b. Objek dari penelitian ini adalah sebagai upaya meningkatkan keaktifan belajar siswa dengan menerapkan metode eksperimen dalam pembelajaran IPA.

Penelitian ini akan dilaksanakan pada semester I selama 3 (tiga) bulan mulai dari tahap persiapan, pelaksanaan tindakan sampai penyusunan laporan.
Jenis penelitian yang dilakukan dalam penelitian ini adalah jenis Penelitian Tindakan Kelas (classroom action research) yang mengarah kepada penggunaan metode eksperimen terhadap keaktifan belajar siswa pada pelajaran IPA di kelas IX.8 SMP Negeri 4 Tebing Tinggi.

\section{HASIL PENELITIAN DAN PEMBAHASAN}

Berdasarkan latar belakang masalah dan rumusan masalah pada penelitian ini, maka untuk meningkatkan keaktifan belajar siswa digunakan metode eksperimen pada pelajaran IPA pokok bahasan sistem reproduksi pada manusia. Peneliti sebelumnya telah menyusun perencanaan kegiatan pembelajaran dengan menggunakan metode eksperimen untuk dilakukan pada siklus I. Hasil pengamatan guru kelas tentang penerapan metode eksperimen tindakan siklus I pada pertemuan I yaitu 68,75\% (kurang baik), tampak bahwa pelaksanaan pembelajaran yang dilakukan guru telah berjalan dengan baik, meskipun demikian pada beberapa aspek masih tergolong cukup baik, misalnya evaluasi akhir kegiatan eksperimen oleh guru, beberapa aspek yang lain sudah tergolong baik, misalnya mendiskusikan hambatan dan hasil eksperimen bersama seluruh siswa. Hasil pengamatan guru kelas tentang penerapan metode eksperimen tindakan siklus I pada pertemuan II yaitu 78,12\% (cukup baik), tampak bahwa pelaksanaan pembelajaran 
yang dilakukan guru telah berjalan dengan baik, meskipun demikian pada beberapa aspek masih tergolong cukup baik, misalnya evaluasi akhir kegiatan eksperimen oleh guru, akan tetapi pada beberapa aspek yang lain sudah tergolong baik, misalnya mendiskusikan hambatan dan hasil eksperimen bersama seluruh siswa.

Persentasi penerapan metode eksperimen selama tindakan siklus I pada pertemuan I dan pertemuan II yang dilakukan oleh guru berbeda pada setiap pertemuan. Untuk mengetahui nilai keaktifan siswa selama kegiatan pembelajaran siklus I pertemuan I dan pertemuan II berdasarkan pengamatan guru. Hasil pengamatan pada siklus I pertemuan I, terdapat 4 orang siswa $(11,43 \%)$ yang keaktifan belajarnya sangat aktif, 6 orang siswa $(17,14 \%)$ yang keaktifan belajarnya tergolong aktif, 8 orang siswa $(22,86 \%)$ yang keaktifan belajarnya cukup aktif, namun 17 orang siswa $(48,57 \%)$ yang keaktifan belajarnya kurang aktif. Sedangkan pada siklus I pertemuan II, terdapat 5 orang siswa $(14,29 \%)$ yang keaktifan belajarnya sangat aktif, 7 orang siswa (20\%) yang keaktifan belajarnya tergolong aktif, 9 orang siswa $(25,71 \%)$ yang keaktifan belajarnya cukup aktif, namun 14 orang siswa (40\%) yang keaktifan belajarnya masih kurang aktif.

Hasil pengamatan observer tampak keaktifan belajar siswa dalam melakukan aktivitas mendengar dan menulis tergolong kategori cukup aktif dan keaktifan siswa dalam aktivitas berbahasa masih tergolong kurang. Hasil pengamatan guru Kelas VII tentang pelaksanaan kegiatan pembelajaran dengan menggunakan metode eksperimen yang dilakukan oleh guru selama tindakan siklus I pertemuan I yaitu $68,75 \%$ (kurang baik) sedangkan pelaksanaan pembelajaran yang dilakukan oleh guru selama tindakan siklus I pertemuan II yaitu $78,12 \%$ (cukup baik).

Dengan demikian, dari hasil tindakan siklus I diperoleh kesimpulan sementara bahwa pembelajaran IPA menggunakan metode eksperimen belum sepenuhnya menjadikan siswa aktif dalam pembelajaran dimana pada pertemuan I 17 orang siswa $(48,57 \%)$ dan pada pertemuan II sebanyak 14 orang siswa (40\%) yang masih memiliki keaktifan belajar tergolong kurang aktif. Karenanya diperlukan tindakan siklus II untuk lebih meningkatkan keaktifan belajar siswa dengan mengadakan kerja kelompok, pemberian tugas, dan tanya jawab menggunakan metode eksperimen, serta lebih memberikan motivasi dan kesempatan berpikir dan bertanya kepada para siswa selama kegiatan eksperimen berlangsung di dalam kelas.

Beranjak dari hasil tindakan siklus I, maka untuk meningkatkan keaktifan belajar siswa agar lebih baik diadakan kerja kelompok, pemberian tugas dan tanya jawab menggunakan metode eksperimen pada pelajaran IPA pokok bahasan Sitem reproduksi pada manusia. Hasil pengamatan guru kelas tentang 
Abd. Kadir : Upaya Meningkatkan Keaktifan ...

penerapan metode eksperimen tindakan siklus II pertemuan I yaitu $87,5 \%$ (baik), seperti yang dirangkum pada tabel 4.5, tampak bahwa pelaksanaan pembelajaran dengan menggunakan metode eksperimen yang dilakukan guru telah berjalan dengan baik. Pada siklus II kelengkapan peralatan, bahan dan sarana yang dibutuhkan dalam penerapan eksperimen sudah tergolong sangat baik. Hasil pengamatan guru kelas tentang penerapan metode eksperimen tindakan siklus II pertemuan I yaitu 93,75\% (sangat baik), seperti yang dirangkum pada tabel 4.6, tampak bahwa pelaksanaan pembelajaran dengan menggunakan metode eksperimen yang dilakukan guru telah berjalan dengan baik. Pada siklus II kelengkapan peralatan, bahan dan sarana yang dibutuhkan dalam penerapan eksperimen sudah tergolong sangat baik. Nilai keaktifan belajar siswa selama pelaksanaan tindakan siklus II pertemuan I dan pertemuan II berdasarkan pengamatan guru. Hasil pengamatan pada siklus II pertemuan I, terdapat terdapat 9 orang siswa $(25,71 \%)$ yang keaktifan belajarnya sangat aktif, 15 orang siswa $(42,86 \%)$ yang keaktifan belajarnya aktif dan 4 orang siswa $(11,43 \%)$ yang keaktifan belajarnya cukup aktif, dan 7 orang siswa (20\%) yang keaktifan belajarnya masih tergolong kurang aktif. Sedangkan hasil pengamatan pada siklus II pertemuan II terdapat 10 orang siswa $(28,57 \%)$ yang keaktifan belajarnya sangat aktif, 16 orang siswa $(45,71 \%)$ yang keaktifan belajarnya aktif dan 6 orang siswa $(17,14 \%)$ yang keaktifan belajarnya cukup aktif, dan 3 orang siswa $(8,57 \%)$ yang keaktifan belajarnya tergolong kurang aktif. Dengan demikian, keaktifan belajar siswa setelah diterapkan tindakan siklus II sudah tergolong baik, telah diperoleh ketuntasan belajar secara klasikal yakni 84\% siswa yang aktif.

Hasil pengamatan guru kelas tentang penerapan metode eksperimen tindakan siklus II pertemuan I yaitu $87,5 \%$ (baik), sedangakan pengamatan guru kelas pada siklus II tindakan II yaitu 93,75\% (sangat baik). Dengan demikian tampak jelas adanya peningkatan persentasi penerapan metode eksperimen pada tindakan siklus I sampai tindakan siklus II. Keaktifan belajar siswa pada tindakan siklus II jauh lebih baik, hal ini tampak bahwa keaktifan siswa dalam melakukan aktivitas melihat dan melakukan aktivitas emosional telah tergolong sangat baik. Keaktifan siswa dalam aktivitas berbahasa, aktivitas mendengarkan, aktivitas menulis, aktivitas menggambar, aktivitas gerak, dan aktivitas mental telah tergolong baik.

Dengan demikian, hasil tindakan silkus II diperoleh kesimpulan bahwa pembelajaran IPA dengan menggunakan metode eksperimen dapat meningkatkan keaktifan belajar siswa Kompetensi Dasar Sistem reproduksi pada manusia di kelas IX.8 SMP Negeri 4 Tebing Tinggi Tahun Pelajaran 2017/2018. 


\section{Pembahasan}

Selama diberikan tindakan siklus I dengan menggunakan metode ceramah, tanya jawab, kerja kelompok, pemberian tugas dan penerapan metode eksperimen keaktifan belajar siswa pada siklus I pertemuan I yaitu dari 35 siswa terdapat 4 orang siswa $(11,43 \%)$ yang keaktifan belajarnya sangat aktif, 6 orang siswa $(17,14 \%)$ yang keaktifan belajarnya tergolong aktif, 8 orang siswa $(22,86 \%)$ keaktifan belajarnya cukup aktif, namun 17 orang siswa $(48,57 \%)$ yang keaktifan belajarnya kurang aktif, sedangkan pada siklus I pertemuan II terdapat 5 orang siswa $(14,29 \%)$ yang keaktifan belajarnya sangat aktif, 7 orang siswa (20\%) yang keaktifan belajarnya tergolong aktif, 9 orang siswa $(25,71 \%)$ yang keaktifan belajarnya cukup aktif, namun 14 orang siswa (40\%) yang keaktifan belajarnya kurang aktif. Berdasarkan hasil siklus I, perlu dilakukan tindakan siklus II untuk lebih meningkatkan keaktifan belajar siswa dengan tetap menggunakan metode ceramah, tanya jawab, kerja kelompok, pemberian tugas dan penerapan metode eksperimen selama kegiatan pembelajaran berlangsung. Selama pelaksanaan kegiatan pembelajaran pada siklus II keaktifan belajar siswa meningkat lebih baik dibandingkan siklus I, hasil pengamatan pada siklus II pertemuan I yaitu dari 35 siswa terdapat 9 orang siswa $(25,71 \%)$ yang keaktifan belajarnya sangat aktif, 15 orang siswa $(42,86 \%)$ yang keaktifan belajarnya aktif dan 4 orang siswa
$(11,43 \%)$ yang keaktifan belajarnya cukup aktif, dan 7 orang siswa (20\%) yang keaktifan belajarnya masih tergolong kurang aktif. Sedangkan hasil pengamatan pada siklus II pertemuan II terdapat 10 orang siswa $(28,57 \%)$ yang keaktifan belajarnya sangat aktif, 16 orang siswa $(45,71 \%)$ yang keaktifan belajarnya aktif dan 6 orang siswa $(17,14 \%)$ yang keaktifan belajarnya cukup aktif, hanya 3 orang siswa $(8,57 \%)$ yang keaktifan belajarnya tergolong kurang aktif. Hal ini menunjukkan bahwa kegiatan pembelajaran dengan penerapan metode eksperimen serta menggunakan metode ceramah, tanya jawab, kerja kelompok, dan pemberian tugas dapat meningkatkan keaktifan belajar siswa jauh lebih baik, meskipun terdapat 3 orang $(8,57 \%)$ yang masih memiliki keaktifan belajar tergolong kurang aktif, yang berarti 32 orang $(91,43 \%)$ telah tergolong keaktifan belajarnya cukup aktif, aktif dan sangat aktif. Persentasi hasil keaktifan belajar siswa berdasarkan pengamatan observer pada tindakan siklus I pertemuan I yaitu $71,52 \%$ (cukup aktif), siklus I pertemua II yaitu $72,30 \%$ (cukup aktif), sedangkan persentasi hasil keaktifan belajar siswa pada tindakan siklus II pertemuan I yaitu $82,30 \%$ (aktif), siklus II pertemuan II yaitu $84,01 \%$ (aktif). Hasil pengamatan guru kelas tentang penerapan metode eksperimen tindakan siklus I pertemuan I yaitu $68,75 \%$ (cukup baik), siklus I pertemuan II yaitu $78,12 \%$ (cukup baik), sedangkan hasil 
Abd. Kadir : Upaya Meningkatkan Keaktifan ...

pengamatan guru kelas tentang penerapan metode eksperimen tindakan siklus II pertemuan I yaitu $87,5 \%$ (baik) dan siklus II pertemuan II yaitu 93,75\% (sangat baik). Dengan demikian tampak jelas adanya peningkatan persentasi penerapan metode eksperimen pada tindakan siklus I sampai tindakan siklus II.

\section{SIMPULAN}

Berdasarkan hasil penelitian dan pembahasan yang telah diuraikan, diperoleh beberapa kesimpulan antara lain: Pada tindakan siklus I pertemuan I, diperoleh persentase keaktifan belajar siswa sebesar 71,52\% sedangkan pada pertemuan II sebesar 72,3\%. Pada tindakan siklus II pertemuan I, diperoleh persentase keaktifan belajar siswa sebesar 82,3\% sedangkan pada pertemuan II sebesar $84,01 \%$. Terjadi peningkatan persentase keaktifan belajar siswa dari siklus I ke siklus II sebesar 11,71 dengan menggunakan metode eksperimen.

Terbukti bahwa dengan menggunakan metode eksperimen dapat meningkatkan keaktifan belajar siswa pada mata pelajaran IPA di kelas IX.8 SMP Negeri 4 Tebing Tinggi T.P. 2017/2018."

\section{DAFTAR RUJUKAN}

Ananda, L. J. 2011. Upaya peningkatan motivasi dan hasil belajar siswa dengan menerapkan pembelajaran aktif, kreatif, efektif dan menyenangkan (PAKEM) pada mata pelajaran IPA siswa kelas
IV MIS Nurul Hidayah

(Doctoral dissertation,

UNIMED).

Arikunto, Suharsimi. 2010. Prosedur

Penelitian Suatu Pendekatan

Praktik. Jakarta: Rineka Cipta.

Arikunto, dkk. 2010. Penelitian

Tindakan Kelas. Jakarta:

Bumi Aksara.

HM, Ahmat Rohani. 2010.

Pengelolaan Pengajaran

Sebuah Pengantar Menuju

Guru Profesional. Jakarta: Rineka Cipta.

N.K, Roestiyah. 2008. Strategi Belajar Mengajar. Jakarta: Rineka Cipta.

Slameto. 2010. Belajar dan FaktorFaktor yang Mempengaruhinya. Jakarta: Rineka Cipta.

Trianto. 2010. Model Pembelajaran

Terpadu. Jakarta: Bumi Aksara. 